\title{
Toward a new conceptualization of household adaptive capacity to climate change: applying a risk governance lens
}

\author{
Carmen E. Elrick-Barr ${ }^{1}$, Benjamin L. Preston $^{2}$, Dana C. Thomsen $^{1}$ and Timothy F. Smith ${ }^{1}$
}

\begin{abstract}
Increasing evidence highlights the importance of context-specific understanding of the impacts of climate change and the need to move beyond generalized assumptions regarding the nature and utility of adaptive capacity in facilitating adaptation. The household level of impact and response is an under-researched context, despite influential decisions affecting local and system vulnerability being made at this scale. Assessments of household adaptive capacity currently assess the influences of adaptive capacity or the influences on adaptive capacity in isolation. We argue that comprehensive assessments need to examine these influences in combination to capture a dynamic and integrated view of households that better reflects their positioning and role(s) in broader socialpolitical contexts. To transition assessments away from examining households as discrete units to recognizing their role within a larger governance context, we outline four themes focused on: (1) analysis of governance contexts, (2) determination of adaptive capacity sources, (3) assessment of cross-scalar trade-offs, and (4) integrated goal setting to facilitate boundary critiques. By considering these themes, the relationships between capacities and actions are highlighted, and the simultaneous outcomes of adaptive choices at individual and broader system scales can be evaluated. We argue that such boundary critique has the potential to yield a more comprehensive assessment of adaptive capacity focused upon cross-scalar influences and impacts.
\end{abstract}

Key Words: adaptation; adaptive capacity; climate change; household; multi-scale

\section{INTRODUCTION}

The global community is committed to degrees of warming that will deliver significant changes and associated challenges for social and environmental systems (Adger and Barnett 2009, IPCC 2013, Peters et al. 2013). Although climate risk management efforts to date have largely focused on policies and technologies for greenhouse gas mitigation, adaptation policy and practice have emerged rapidly in recent years (Jones and Preston 2011, Park et al. 2012). The implementation of adaptation policies and options, however, is contingent on the capacity of institutions, organizations, and actors (Adger et al. 2007, Nelson et al. 2007, Brown and Westaway 2011), and such capacity varies significantly among regions, communities, and sectors (Adger et al. 2007). Building adaptive capacity has the potential to reduce vulnerability to climate impacts by supporting adaptive action (Smit and Wandel 2006) and contributing to system resilience by enabling adaptation and transformation (Marshall et al. 2012, Rickards and Howden 2012). Hence, adaptive capacity research that identifies the attributes of agents, institutions, and locales that facilitate adaptive action (Adger et al. 2004, Brooks et al. 2005) is an important vehicle for building adaptive capacity and facilitating adaptive actions.

Various studies have illustrated that adaptation processes often involve decision making across multiple scales of social organization (Few et al. 2004, Olwig 2012, Hill and Engle 2013). However, adaptation research and practice has tended to focus on the actions of formal public institutions such as local/ municipal or national governments (Tompkins et al. 2010, Eakin et al. 2011, Measham et al. 2011, Moser and Ekstrom 2011). Climate change impacts and adaptation responses at the household scale are also important foci for adaptation research because many investment and consumption decisions that affect individual vulnerability to climate hazards, as well as system resilience, are made at this scale (Eakin and Wehbe 2009, Waitt et al. 2012). The household scale has been a focus of study across a range of fields, including poverty reduction (Bebbington 1999), hazard management (Cutter et al. 2008), human resilience (Patterson 2002, Norris et al. 2008), and more recently, climate change adaptation (Hayden et al. 2011). A common goal of these studies is the identification of attributes or elements that build resilience or aid adaptation for specific risks. Various determinants such as financial capital and risk perception have been associated with the implementation of adaptive actions (Grothmann and Patt 2005, Tucker et al. 2010, Harvatt et al. 2011, Linnekamp et al. 2011). Subsequently, strategies to enhance the availability of, or access to, these determinants have been promoted as means of enhancing adaptive capacity.

Nevertheless, many of the aforementioned studies are based only on an initial assessment of adaptive capacity as a function of the availability of particular assets or the household's perception of risk. These approaches to assessment are grounded in social vulnerability assessment and livelihoods analysis, which generally frame social capacity as a function of entitlements to resources or capital (Nelson et al. 2010, Keskitalo et al. 2011). However, such approaches often exclude consideration of the underlying social and institutional processes that create capacity, the motivations and objectives of actors that underpin adaptive action, or the effectiveness of those actions in reducing vulnerability over various spatial and temporal scales (e.g., Adger and Kelly 1999, Thomsen et al. 2012, Tschakert et al. 2013). Furthermore, there is little critical evaluation of who benefits and who loses as a result of the adaptive actions that are implemented (Smit et al. 2000, Brown 2011, Jennings 2011), how actions are supported or constrained by cross-scale social-ecological factors and interactions (see Eakin and Wehbe 2009, Fernández-Giménez et al. 2012), or how actions at the household scale link to higher 
levels of social organization. As such, there are a number of gaps in the assessment of household adaptive capacity that might limit its contribution to policy development for vulnerability reduction or enhanced system resilience.

The lens of risk governance might provide a more productive pathway for framing the assessment of household adaptive capacity (Renn 2008, see also Armitage and Plummer 2010). Conceptually, risk governance promotes consideration of risk and multiple values, objectives, and interests (van Asselt and Renn 2011). It also recognizes that outcomes of management strategies (or adaptation policies and options) might not meet all of the social, environmental, or economic criteria held by stakeholders (Renn 2008). As such, trade-offs in values are an unavoidable element of decision making, and therefore, consultative and participatory processes are promoted as a means of legitimizing the decision-making process (Renn and Schweizer 2009). Adopting a risk governance lens shifts assessment of adaptive capacity from the enumeration of discrete assets held by households toward the consideration of how households respond to risk within a broader governance context. This allows the assessment process to engage the social and environmental factors that shape adaptive capacity (influences on adaptive capacity) as well as the outcomes of adaptive choices (influences of adaptive capacity).

Our objective is to articulate a framework for assessing household adaptive capacity that addresses the gaps identified in previous work by situating households within a risk governance context. This approach is supported by transitions in vulnerability and resilience research from a focus on the ability to deliver action to consideration of the process of adaptation itself: how it is shaped, the outcomes delivered, and who wins and loses as a result (Adger et al. 2011a,b, Brown 2011, Eriksen et al. 2011, Jennings 2011). We commence by describing the role of households in the governance of climate and other risks, and then identify emergent gaps associated with assessments of household adaptive capacity. We then present a framework for boundary critique using climate change impacts to water resource reliability as an illustrative application. We argue that this framework enables consideration of the interdependent nature of adaptive capacity in an inclusive and participatory decision-making environment that has the potential to yield a more comprehensive assessment focused on cross-scalar influences and impacts.

\section{THE GOVERNANCE OF RISK AND HOUSEHOLD ADAPTIVE CAPACITY}

Risk governance concerns risk-related decision making that involves a range of actors, requiring coordination and potentially reconciliation of different roles, perspectives, goals, and activities (Renn 2005). By assisting decision-making processes in situations where risks are uncertain, complex, or ambiguous (van Asselt and Renn 2011), risk governance offers significant potential for "wicked" issues such as climate change (Head 2008, Levin et al. 2012). In contrast to assessments that seek to reduce adaptive capacity to a small number of static determinants, the risk governance lens recognizes the political ecology of the development of adaptive capacity, as well as its application in adaptation policy and practice.

Decisions made at the household scale such as investment strategies, diet, political support, mode of transport, education, and training are shaped by individual, local, contextual, and multi-scale factors (Adger et al. 2009). These decisions have consequences at larger scales of social-ecological organization, affecting other actors, organizations, and institutions. As such, household-scale decisions can influence system vulnerability and sustainability (Eakin and Wehbe 2009, Brown 2011). For example, the decision to purchase a home is shaped by individual values (renting versus owning), social relationships (who lives nearby), price (local and global economies), planning restrictions (building type and location), and access to insurance, among many others. Selecting a home situated in a low-lying coastal plain vs. a highland area might influence exposure to flood hazard, whereas the adoption of self-protection actions such as a flood-training wall might alter the scenic amenity of a location and/or reduce the buffering capacity of a downstream coastline. Selecting to rent rather than own a home can influence householder capacity to make structural or technological modifications to reduce exposure to indirect climate hazards while also affecting the ability to mitigate climate change (e.g., installing grey water systems or solar panels). Hence, the effects of particular adaptation responses at the household level might not be confined to those households. Rather, other actors and organizations may participate in, or be affected by, adaptation responses.

A household is therefore one element within a larger, complex system of governance that influences vulnerability to hazards that arise from climate change (Fig. 1). This complexity poses challenges for effective household responses to manage risk. It also poses challenges for research investigating the role of household adaptive capacity in mediating those responses. To understand household adaptive capacity as it contributes to system resilience and vulnerability reduction, it is important to identify (1) the effects of governance processes on adaptive capacity, and (2) the effects of adaptive capacity on the planning, implementation, and outcomes of adaptation actions at the household scale. These two facets of adaptive capacity are currently explored by distinct, yet overlapping, areas of research. One focuses on system sustainability or pro-environmental behavior, examining the influences on adaptive capacity as they shape household behaviors or adaptive choice. The other focuses on household vulnerability reduction, examining the effects of adaptive capacity on reducing exposure and sensitivity to hazard

Fig. 1. The household as an element of the governance system.

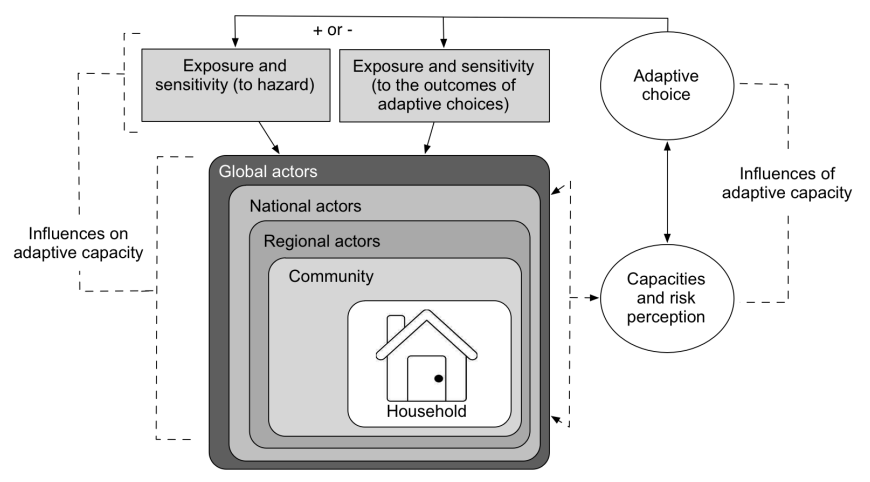

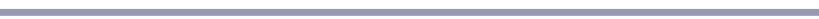


events (Fig. 2). However, the elements of and on adaptive capacity are often addressed in isolation, and this lack of integration creates gaps in understanding the role of the household in adaptation. These gaps, as well as pathways by which they can be addressed, are outlined in the following sections.

Fig. 2. (A) Traditional framing of influences of adaptive capacity on adaptive action. Those with capacity and/or perception of risk take adaptive action. The action reduces vulnerability to the select hazard. (B) Traditional framing of studies that explore influences on adaptive capacity. The household response to a select policy is viewed as a product of the broader system as well as individual attributes. The implications of adaptive choice (behaviors in response to policy) on system sustainability are considered.
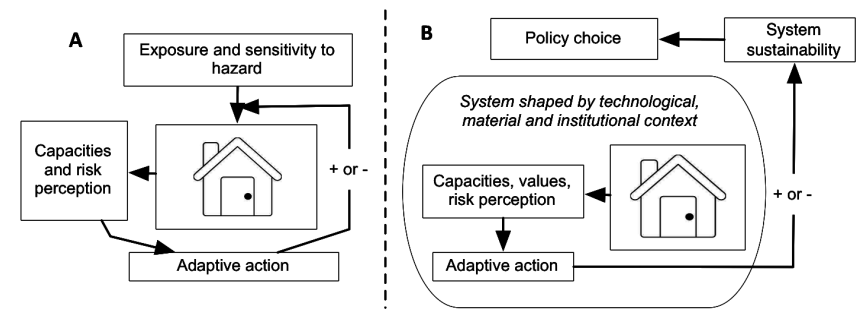

\section{INFLUENCES ON ADAPTIVE CAPACITY}

Household-scale assessments of adaptive capacity that focus on vulnerability reduction have their traditions in the fields of hazard management, global environmental change, and sustainable livelihoods (McLaughlin and Dietz 2008, Miller et al. 2010). Their objective is to generate knowledge that can enhance capacity to reduce exposure and sensitivity to hazards (Grothmann and Reusswig 2006, Vincent 2007, Molua 2009, Kalikoski et al. 2010, Harvatt et al. 2011, Below et al. 2012, Saroar and Routray 2012). These studies identify attributes of households that have taken action in response to stress, which may be informed by experience with past events or by theoretical or conceptual models of causeand-effect relationships between households and their socialecological context. The implicit or explicit assumption underpinning such studies is that by facilitating access to capital (e.g., financial or human), households will have the material and social resources required to implement actions (Fig. 2).

However, the focus on household attributes, exclusive of the attributes or characteristics of other actors within the system and how they influence household access, results in an isolated and static view of the household. Few studies look at processes exogenous to the household as important influences on adaptive capacity (although see Osbahr et al. 2008, Fernández-Giménez et al. 2012). For example, although cross-scale interactions among actors are, in some cases, discussed as a mechanism that influences household access to determinants of adaptive capacity (Grothmann and Patt 2005), this influence is rarely analyzed as a component of the assessment. Consequently, there is a focus on household entitlements, exclusive of the community, regional, or national contexts (including social, material, technological, cultural, and political) that shape entitlements. Ultimately, this results in an incomplete picture of household adaptive capacity that reveals little about where interventions to enhance capacity can be made. For example, although enhancing the knowledge of households about climate risk is often considered to enhance adaptive capacity (Marshall et al. 2013), without understanding the pathways by which households receive such knowledge (e.g., roles of other actors) as well as how such knowledge is used in decision making, it may be difficult to translate knowledge into capacity. Furthermore, investments made in enhancing the capacity of households may result in trade-offs or opportunity costs that may go unrecognized if households are considered in isolation.

In contrast, exploring the influences on adaptive capacity using a risk governance lens results in a richer understanding of the various actors and driving forces influencing household behavior. For example, sustainability and pro-environmental behavior studies examine policy settings, available technologies, and social and cultural contexts to understand the determinants of household environmental behavior (DEFRA 2005, 2008, OECD 2008, Spence and Pidgeon 2009, Maller and Strengers 2011, Strengers and Maller 2012). The effects of alternate policy mechanisms (e.g., economic instruments, labeling, information campaigns, and direct regulation) on household capacities and, in turn, associated behaviors, is explored in an effort to understand the range of mechanisms that influence decision making for sustainability at the household scale. For example, market-based mechanisms such as rebates for investment in water-efficient equipment seek to address barriers in financial capital, whereas information campaigns seek to influence values and perceptions. Alternatively, regulation (e.g., building standards) does not directly target household capacity; rather, the environment in which households operate indirectly shapes patterns of consumption and other routine behaviors. The risk governance lens expands understanding regarding how behaviors are shaped by external governance, social, and cultural contexts. This translates into exploring and understanding the degree to which external factors influence or hinder the implementation of adaptive action via its influence on the capacities that shape action.

\section{INFLUENCES OF ADAPTIVE CAPACITY}

Household adaptive capacity can also be assessed based on the outcomes it generates, i.e., the actions implemented and their associated costs and benefits for human and natural systems. However, interventionist and equity principles have shaped household-level assessments that seek to reduce vulnerability (Kuhlicke et al. 2011), and assessments have sought to deliver equity in access to resources, rather than critique the outcomes of the actions implemented (Sen 1981, Blackwood and Lynch 1994, Moser 1998, Scoones 1998, Bebbington 1999, Siegel 2005). Thus, although the link between capacity and the ability to take action (influences of adaptive capacity) is examined, there is limited critical review of the implications of selected adaptive actions in achieving positive outcomes, either for the individual household or the broader system. Rather, high levels of adaptive capacity are assumed to lead to adaptive action that reduces individual and community vulnerability (i.e., Below et al. 2012; Fig. 2a). Jennings (2011) argues that by making this assumption, studies exclude consideration of the political nature of adaptation. Adaptive capacity may be deployed to support adaptive or maladaptive actions; therefore, higher adaptive capacity does not necessarily lead to a reduction in vulnerability 
Fig. 3. Indicative example of progressing through the themes that facilitate boundary critique for the assessment of household adaptive capacity. Adapted from Eisenack and Stecker (2012).

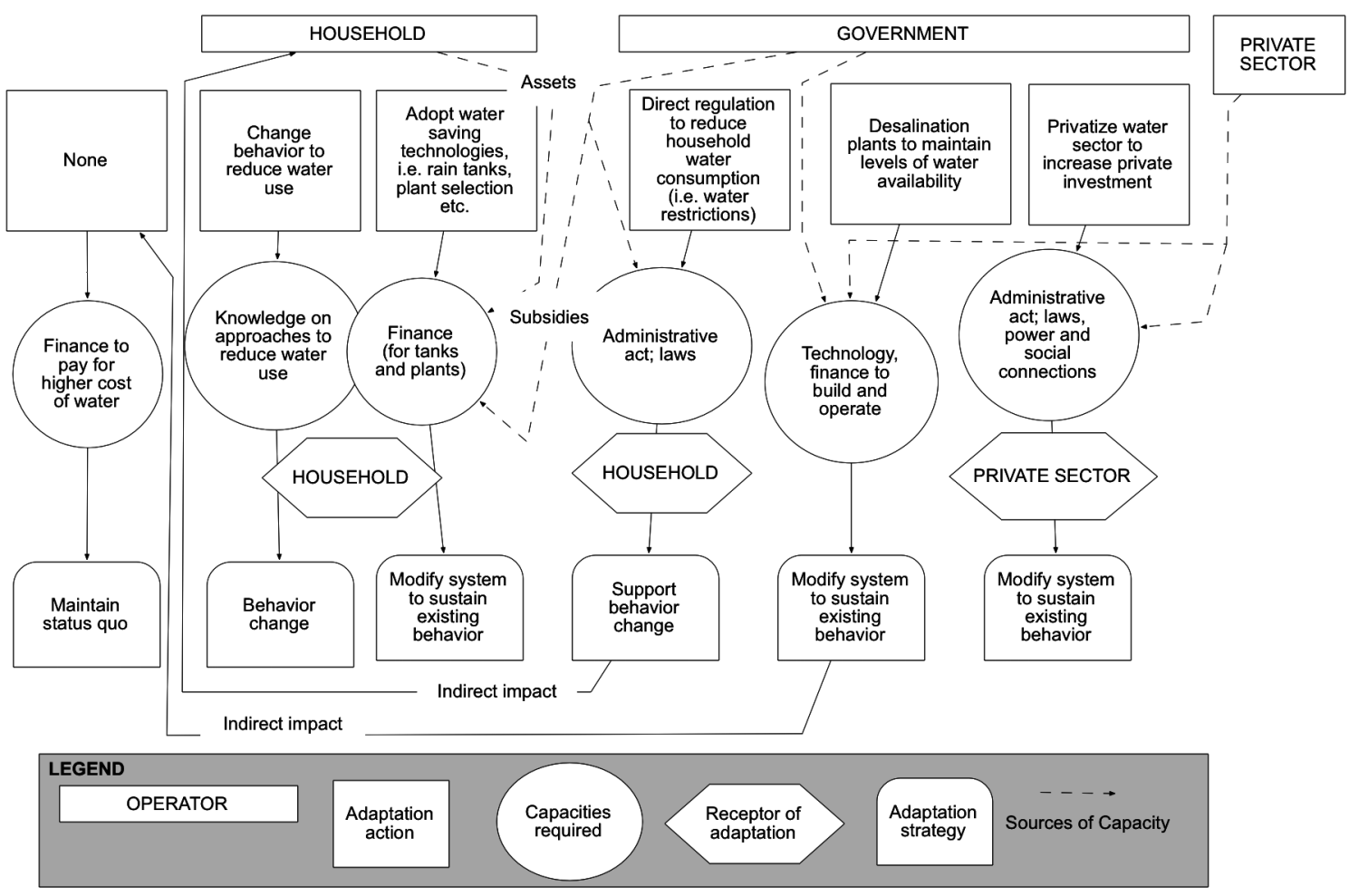

(Barnett and O’Neill 2010). Consequently, the determinants of capacity that are promoted may support adaptive actions that are ineffective at the individual household and/or system scale.

Understanding how available capacities influence adaptive choice and the contribution of those adaptive choices to vulnerability reduction and system sustainability is therefore important in adaptive capacity assessment. This involves judgements on the link between capacity and action as well as the appropriateness of particular adaptive choices in achieving end goals. Strengers and Maller (2012) address this issue, in part, by exploring the link between systems of energy and water resource provision and householders' capacity to adapt to climate change. Different strategies of resource provision are argued to influence the degree to which householders conserve resources. In this example, a link between capacity and action is proposed, and assumptions regarding the appropriateness of actions (i.e., level of resource conservation by behaviour type) are specified; however, the end goal sought via intervention and an approach to transition toward the end goal (e.g., reducing consumption by raising the price of the resource) is not stated. Consequently, practical recommendations that address the sustainability issues identified are not forthcoming.

This raises a key challenge in adaptive capacity assessment: defining what is appropriate action given the complexity of the risk and the diverse values both of those involved in decision making and those affected by the decision. Addressing this challenge requires a participatory and inclusive approach (Renn and Schweizer 2009, Renn and Klinke 2012). Consequently, adaptive capacity assessment should consider (1) who will be included in the process to define adaptation goals and specify the links between capacity and action, and (2) by what process (including procedural rules) a final decision will be reached (Renn and Schweizer 2009). In this way, the anticipated outcomes of capacity building interventions are defined in an inclusive manner, which is necessary for climate risks characterized by uncertainty, ambiguity, and diverse values.

\section{TOWARD A NEW CONCEPTUALIZATION OF HOUSEHOLD ADAPTATION AND ADAPTIVE \\ CAPACITY}

The previous sections demonstrate that common ways of framing household adaptive capacity in research neglect key elements needed for comprehensive understanding of the role of the household in adaptation. The lack of an integrated focus regarding influences on and influences of capacity is a product of the assessment scope, framing, and conduct (Midgley and Reynolds 2004). By expanding the boundaries of household-scale adaptive capacity assessment, influences on and influences of adaptive capacity can be considered in unison, providing a richer understanding of system complexity to move beyond generalized assumptions regarding the utility of adaptive capacity in facilitating action.

To this end, we outline four themes that facilitate boundary critique for the assessment of household adaptive capacity (Ulrich $2000,2005)$. These themes focus on context determination prior to goal setting. Details of the current system are elucidated 
(themes 1 and 2) prior to the collaborative definition of adaptation strategies (theme 3 ) and capacity building goals (theme 4). The themes assist in integrating core concepts of risk governance into the assessment process. Themes 1 and 2 involve establishing the system framing, ensuring that the systemic nature of risk and capacity is considered (Renn et al. 2011). Theme 3 allows for participatory and inclusive decision making in assessing crossscalar influences and defining adaption strategies, noting that communication and participation are important aspects in all themes (Renn and Schweizer 2009). In theme 4, the outcomes of themes $1-3$ are critically reflected on to identify entry points for adaptive capacity enhancement that builds on collective and complementary actions across scales (Eakin and Wehbe 2009, Hill and Engle 2013). The themes do not represent a prescriptive approach to household adaptive capacity assessment. Rather, they provide guidance to frame assessments broadly and capture a comprehensive range of influences of and on adaptive capacity.

Drawing on Eisenack and Stecker's (2012) framework of adaptation as actions to map the actors involved, adaptive choices, capacities required, and resultant adaptive strategies, we demonstrate the utility of these themes for enhancing assessment using the scenario of water resource reliability for a particular household (Fig. 3). This scenario demonstrates how mapping the interplay between household decisions and climate risk management decisions across scales can reveal the role households play in the adaptation process, clarifying entry points for adaptive action (e.g., behavior change) and highlighting areas for adaptive capacity enhancement (e.g., information provision and/or augmentation of financial capital). Assessing adaptive capacity requires an understanding of the end goal of adaptation; therefore, adaptation choices (theme 1) and strategies (theme 3) are discussed within the themes.

\section{Theme 1: analysis of governance contexts}

Theme 1 establishes the scope and bounds of the assessment by positioning the household within the governance structure for a particular problem/issue. Although it is tempting to frame adaptive choices by only considering hazard type and characteristics, the choice of adaptive response and the capacity to implement responses are also a function of the cultural, political, technological, institutional, and environmental contexts of the household. This theme, therefore, focuses the assessment on the evaluation of available adaptive choices that are relevant to a particular hazard and encourages consideration for the role of the household in the adaptation process in the context of the range of conditions and other actors that shape adaptive choice.

Applying this theme to the issue of water resource reliability illustrates a range of adaptive choices available to households and to other actors whose decisions have an influence on household responses (Fig. 3). Although a variety of actors are stakeholders in the management of water resources, for illustrative purposes, this scenario focuses on just two actors with key roles in water management: households and state government. Household adaptive choices can also be considered at different temporal scales relative to other actors (e.g., government agencies, private sector, nongovernmental organizations). Households might take actions prior to other actors and/or they might take actions after or in response to those of other actors. For example, households might adapt by investing in water-saving technologies and changing behavior to reduce water use. This action can be proactive or in response to adaptive actions taken at other scales (e.g., water management policy). Households may also choose not to alter their behavior if they are facilitated to maintain existing status through actions taken at other scales (e.g., a desalination system to ensure access to water, although at a higher cost). Explicit consideration of the sequence of actions among different actors allows identification of responses to direct (i.e., climate) as well as indirect (i.e., policy) effects associated with climate hazards. This provides a preliminary understanding of system complexity and the range of roles that households (and other actors) can play and actions they can pursue in responding to the impacts of a select hazard. More importantly, this theme helps identify and clarify the interdependencies among different actors and how they shape actions across scales.

\section{Theme 2: determination of adaptive capacity sources}

Theme 2 facilitates consideration of the capacities required to take action within the current governance context or to promote a change in the context to broaden the adaptive choices available to the household. Sources of capacity are also considered because different actors can enhance the capacity of households to adapt (for example, through financial subsidies). Exploring the capacity required to implement select strategies can help to develop an understanding of those actors that are more resilient to impacts and also the adaptive strategies that might be implemented by different actors as a function of the available adaptive capacities.

In the water resource reliability scenario, whether and for how long households are able to maintain the status quo of consumption without behavioral change is a function of the capacity of households and the actions taken by other actors in the governance system. For example, if a market-based approach to adaptation is adopted, households with higher capacity, largely owing to access to financial resources, will be more resilient to system changes occurring beyond the household scale (such as privatization). In contrast, households with lower financial capacity must, or might choose to, alter behavior and resource use sooner because the costs of maintaining the status quo pose a substantive behavioral constraint. However, the provision of subsidies to offset costs for those with lower financial capacity could be incorporated into the intervention in an attempt to achieve greater equity in the distribution of costs. Alternatively, if local or State government were to implement water restrictions, financial resources would have less influence on the capacity to respond. In fact, those who have traditionally consumed more may have a more difficult time adapting to the imposed constraint. This scenario demonstrates how adaptive choices are shaped by the demands those choices place on households and the capacity of households to respond. Furthermore, as explored in theme 1, capacity is shaped by other actors at other scales and their adaptive choices, including how issues of fairness are perceived and managed in decision making.

\section{Theme 3: assessment of cross-scalar influences}

Theme 3 allows decision makers to critique the trade-offs in outcomes among different adaptive strategies across scales, considering who wins and loses as a result of the actions implemented. First, discrete adaptive choices are categorized into adaptive strategies to shift attention away from the individual choices themselves to the outcomes sought by adaptation 
(Ziervogel et al. 2006). Subsequently, the systemic effects of adaptation pathways are examined, including potential trade-offs and synergies with other actions or objectives, rather than evaluating adaptation narrowly by assessing the feasibility of implementing a particular option.

Adaptive strategies for managing constraints on water availability can be categorized into those that: (1) support behavior change at the household scale (i.e., knowledge on approaches to reduce water consumption), and (2) seek to sustain existing patterns of behavior at the household scale (i.e., access to financial resources to pay for the higher cost of water; Fig. 3). Adaptation via behavior change (internal or self-regulating modification) is argued to be respectful of the integrity of social-ecological systems, whereas actions that focus on external change or manipulating the system with the aim of making self-regulation unnecessary are termed manipulative actions (in this case, construction of desalination plants to maintain potable water availability, although at a higher cost; Thomsen et al. 2012). Both strategies can address the immediate objective of securing household water availability, but they have very different implications for sustainability outcomes (Barnett and O'Neill 2010), both at the household level and across the governance system.

Classifying adaptive choices into alternate adaptive strategies ensures that the assumptions regarding trade-offs between environmental services and human outcomes are transparent. Given that actors can make different normative judgments regarding the risk of declining water availability as well as the different policy prescriptions to manage that risk (Renn and Klinke 2012), such transparency is necessary to facilitate deliberation that can reconcile such value differences. Further, equity issues associated with adaptation choices made across scales can be explored. For example, the decision to enable households with high financial capacity to continue to maintain high levels of resource use by installing desalination plants can be critically reviewed with respect to how the costs and benefits of such technologies are distributed throughout society. Hence, adaptive capacity assessment can consider negotiation processes associated with managing trade-offs in adaptation and the degree and structure of participation required for the purposes of the assessment (refer to Renn and Schweizer 2009).

\section{Theme 4: integrated goal setting}

What are the barriers and/or enablers to households implementing the adaptation strategies sought? What are the goals of adaptive capacity development? Drawing on an understanding of how the governance context shapes adaptive choice, existing capacity sources, and the trade-offs associated with identified adaptive strategies (as established via themes 13 ), opportunities to enhance capacities that lead to more or directed adaptive choices for households can be evaluated. Interventions to enhance capacity might include structural changes to system interrelationships via changes in institutions and their rules or relationships, as well as augmentation of resources through the delivery of technology, finance, or enhancement of human capital.

In the scenario provided, if the adaptation strategy of behavior change were sought, the identified barriers or opportunities for modifying household water consumption would provide the basis for adaptive capacity interventions. Household adaptation does not occur in isolation from actions and decisions within the broader governance context. Therefore, interventions must provide opportunities for households to take direct action and respond to indirect effects associated with adaptive actions implemented at other scales. For example, a barrier to direct action (identified in theme 1) might be householders' limited awareness of opportunities to modify consumption patterns (identified in theme 2). An approach to achieve behavior change might be to provide information on opportunities for water saving in the home, with information provision guided by an understanding of the way in which households receive and apply information in decision making. Similarly, State governments might perceive the low unit cost of water as a barrier to household behavior change and therefore increase the unit cost of water as an adaptive measure. At the household scale, financial capital to pay for the higher unit cost of water would influence capacity to accommodate this change. To facilitate households in adapting to this change, a means-tested financial subsidy for a specified usage level (e.g., $5 \times 10^{4} \mathrm{~L}_{\text {person }}{ }^{-1} \mathrm{yr}^{-1}$ ) might be provided (WSAA 2010).

Given that different adaptive choices have different implications for households and their capacity to respond, mechanisms to promote deliberation and reconcile different values and costs/ benefits among different actors and scales are required. Through such mechanisms, the contribution of interventions to vulnerability reduction, long-term sustainability, and social equity, among other factors, can be evaluated, with the evaluation criteria defined in an inclusive and collaborative manner. Therefore, elements of understanding adaptive capacity include understanding whether opportunities for such deliberation exist and identifying entry points to enhance opportunities where available.

\section{CONCLUSION}

Here, we have argued that influences of and influences on household adaptive capacity are currently addressed in isolation. We suggest that to understand adaptive capacity as it contributes to system resilience and vulnerability reduction, it is important to identify (1) the effects of governance processes on adaptive capacity, and (2) the effects of adaptive capacity on the planning, implementation, and outcomes of adaptation actions at the household scale. To capture these elements within household adaptive capacity assessments, we outlined four themes that facilitate boundary critique. By considering these themes, the relationship between capacity and action is explored, and in turn, the outcomes of adaptive choices at both the individual and broader system scales are evaluated. This framework progresses household adaptive capacity assessment beyond consideration for individual households toward the consideration of households as one element of a broader system of risk governance. In so doing, the framework acknowledges that deliberative and participatory approaches are critical to ensure transparency in adaptive choices, which is a necessary foundation for the promotion of select determinants of adaptive capacity.

We argue that by framing assessments of adaptive capacity with a risk governance lens, the assumptions that direct the research are explicit and the goals sought from enhancing household capacity are defined. This enables a transition beyond the often 
adopted view that adaptation is a process that is inherently beneficial to a particular actor, to explicitly consider the political nature of adaptation, the broader consequences of adaptation choices at different scales, and the potential winners and losers. Transitioning assessments away from examining households as discrete units to recognizing their role within a larger governance context will require critical review of the traditional boundaries placed on assessment processes. Such boundary critiques will enable household adaptive capacity research to play a more comprehensive role in contributing to system resilience and vulnerability reduction.

Responses to this article can be read online at: http://www.ecologyandsociety.org/issues/responses. php/6745

\section{Acknowledgments:}

This research was supported by the Australian Research Council (ARC-DP1093583). We are thankful for the constructive comments on the manuscript from two anonymous reviewers.

\section{LITERATURE CITED}

Adger, W. N., S. Agrawala, M. M. Q. Mirza, C. Conde, K. O’Brien, J. Pulhin, R. Pulwarty, B. Smit, and K. Takahashi. 2007. Assessment of adaptation practices, options, constraints and capacity. Pages 717-743 in M. L. Parry, O. F. Canziani, J. P. Palutikof, P. J. van der Linden, and C. E. Hanson, editors. Climate change 2007, impacts, adaptation and vulnerability. Contribution of Working Group II to the Fourth Assessment Report of the Intergovernmental Panel on Climate Change. Cambridge University Press, Cambridge, UK. [online] URL: http://www. ipcc.ch/pdf/assessment-report/ar4/wg2/ar4-wg2-chapter17.pdf.

Adger, W. N., and J. Barnett. 2009. Four reasons for concern about adaptation to climate change. Environment and Planning $A 41$ (12):2800-2805. http://dx.doi.org/10.1068/a42244

Adger, W. N., J. Barnett, F. S. Chapin III, and H. Ellemor. 2011a. This must be the place: underrepresentation of identity and meaning in climate change decision-making. Global Environmental Politics 11(2):1-25. http://dx.doi.org/10.1162/GLEP_a_00051

Adger, W. N., N. Brooks, G. Bentham, M. Agnew, and S. Eriksen. 2004. New indicators of vulnerability and adaptive capacity. Tyndall Centre Technical Report 7. Tyndall Centre for Climate Change Research, Norwich, UK. [online] URL: http://www. tyndall.ac.uk/content/new-indicators-vulnerability-and-adaptivecapacity.

Adger, W. N., K. Brown, D. R. Nelson, F. Berkes, H. Eakin, C. Folke, K. Galvin, L. Gunderson, M. Goulden, K. O'Brien, J. Ruitenbeek, and E. L. Tompkins. 2011b. Resilience implications of policy responses to climate change. Wiley Interdisciplinary Reviews: Climate Change 2(5):757-766. http://dx.doi.org/10.1002/ $\underline{\text { wcc. } 133}$

Adger, W. N., H. Eakin, and A. Winkels. 2009. Nested and teleconnected vulnerabilities to environmental change. Frontiers in Ecology and the Environment 7:150-157. http://dx.doi. org/10.1890/070148
Adger, W. N., and P. M. Kelly. 1999. Social vulnerability to climate change and the architecture of entitlements. Mitigation and Adaptation Strategies for Global Change 4(3-4):253-266. http:// dx.doi.org/10.1023/A:1009601904210

Armitage, D., and R. Plummer, editors. 2010. Adaptive capacity and environmental governance. Springer, Berlin, Germany. http:// dx.doi.org/10.1007/978-3-642-12194-4

Barnett, J., and S. O’Neill. 2010. Maladaptation. Global Environmental Change 20(2):211-213. http://dx.doi.org/10.1016/ j.gloenvcha.2009.11.004

Bebbington, A. 1999. Capitals and capabilities: a framework for analyzing peasant viability, rural livelihoods and poverty. World Development 27(12):2021-2044. http://dx.doi.org/10.1016/S0305-750X (99)00104-7

Below, T. B., K. D. Mutabazi, D. Kirschke, C. Franke, S. Sieber, R. Siebert, and K. Tscherning. 2012. Can farmers' adaptation to climate change be explained by socio-economic household-level variables? Global Environmental Change 22(1):223-235. http://dx. doi.org/10.1016/j.gloenvcha.2011.11.012

Blackwood, D. L., and R. G. Lynch. 1994. The measurement of inequality and poverty: a policy maker's guide to the literature. World Development 22(4):567-578. http://dx.doi.org/10.1016/0305-750X (94)90112-0

Brooks, N., W. N. Adger, and P. M. Kelly. 2005. The determinants of vulnerability and adaptive capacity at the national level and the implications for adaptation. Global Environmental Change 15 (2):151-163. http://dx.doi.org/10.1016/j.gloenvcha.2004.12.006

Brown, K. 2011. Sustainable adaptation: an oxymoron? Climate and Development 3(1):21-31. http://dx.doi.org/10.3763/cdev.2010.0062

Brown, K., and E. Westaway. 2011. Agency, capacity, and resilience to environmental change: lessons from human development, well-being, and disasters. Annual Review of Environment and Resources 36:321-342. http://dx.doi.org/10.1146/ annurev-environ-052610-092905

Cutter, S. L., L. Barnes, M. Berry, C. Burton, E. Evans, E. Tate, and J. Webb. 2008. A place-based model for understanding community resilience to natural disasters. Global Environmental Change 18(4):598-606. http://dx.doi.org/10.1016/j.gloenvcha.2008.07.013

DEFRA [Department for Environment, Food and Rural Affairs]. 2005. Changing behaviour through policy making. DEFRA, London, UK.

DEFRA [Department for Environment, Food and Rural Affairs]. 2008. Framework for pro-environmental behaviours. DEFRA, London, UK.

Eakin, H., S. Eriksen, P.-O. Eikeland, and C. Øyen. 2011. Public sector reform and governance for adaptation: implications of new public management for adaptive capacity in Mexico and Norway. Environmental Management 47(3):338-351. http://dx.doi.org/10.1007/ $\underline{\mathrm{s} 00267-010-9605-0}$

Eakin, H. C., and M. B. Wehbe. 2009. Linking local vulnerability to system sustainability in a resilience framework: two cases from Latin America. Climatic Change 93(3-4):355-377. http://dx.doi. org/10.1007/s10584-008-9514-X 
Eisenack, K., and R. Stecker. 2012. A framework for analyzing climate change adaptations as actions. Mitigation and Adaptation Strategies for Global Change 17(3):243-260. http://dx.doi. org/10.1007/s11027-011-9323-9

Eriksen, S., P. Aldunce, C. S. Bahinipati, R. D’Almeida Martins, J. I. Molefe, C. Nhemachena, K. O'Brien, F. Olorunfemi, J. Park, L. Sygna, and K. Ulsrud. 2011. When not every response to climate change is a good one: identifying principles for sustainable adaptation. Climate and Development 3(1):7-20. http://dx.doi. org/10.3763/cdev.2010.0060

Fernández-Giménez, M. E., B. Batkhishig, and B. Batbuyan. 2012. Cross-boundary and cross-level dynamics increase vulnerability to severe winter disasters (dzud) in Mongolia. Global Environmental Change 22(4):836-851. http://dx.doi.org/10.1016/ j.gloenvcha.2012.07.001

Few, R., K. Brown, and E. Tompkins. 2004. Scaling adaptation: climate change response and coastal management in the UK. Tyndall Centre Working Paper 60. Tyndall Centre for Climate Change Research, Norwich, UK. [online] URL: http://www. tyndall.ac.uk/content/scaling-adaptation-climate-change-responseand-coastal-management-uk.

Grothmann, T., and A. Patt. 2005. Adaptive capacity and human cognition: the process of individual adaptation to climate change. Global Environmental Change 15(3):199-213. http://dx.doi. org/10.1016/j.gloenvcha.2005.01.002

Grothmann, T., and F. Reusswig. 2006. People at risk of flooding: why some residents take precautionary action while others do not. Natural Hazards 38(1-2):101-120. http://dx.doi.org/10.1007/ s11069-005-8604-6

Harvatt, J., J. Petts, and J. Chilvers. 2011. Understanding householder responses to natural hazards: flooding and sea-level rise comparisons. Journal of Risk Research 14(1):63-83. http://dx. doi.org/10.1080/13669877.2010.503935

Hayden, M. H., H. Brenkert-Smith, and O. V. Wilhelmi. 2011. Differential adaptive capacity to extreme heat: a Phoenix, Arizona, case study. Weather, Climate, and Society 3(4):269-280. http://dx.doi.org/10.1175/WCAS-D-11-00010.1

Head, B. 2008. Wicked problems in public policy. Public Policy 3 (2):110-118.

Hill, M., and N. L. Engle. 2013. Adaptive capacity: tensions across scales. Environmental Policy and Governance 23(3):177-192. http:// dx.doi.org/10.1002/eet.1610

IPCC [Intergovernmental Panel on Climate Change]. 2013. Summary for policy makers. Pages 3-29 in T. F. Stocker, D. Qin, G.-K. Plattner, M. Tignor, S. K. Allen, J. Boschung, A. Nauels, Y. Xia, V. Bex, and P. M. Midgley, editors. Climate change 2013: the physical science basis. Contribution of Working Group I to the Fifth Assessment Report of the Intergovernmental Panel on Climate Change. Cambridge University Press, Cambridge, UK. [online] URL: http://www.climatechange2013.org/images/report/ WG1AR5 SPM FINAL.pdf.

Jennings, T. L. 2011. Transcending the adaptation/mitigation climate change science policy debate: unmasking assumptions about adaptation and resilience. Weather, Climate and Society 3:238-248. http://dx.doi.org/10.1175/WCAS-D-11-00056.1
Jones, R. N., and B. L. Preston. 2011. Adaptation and risk management. Wiley Interdisciplinary Reviews: Climate Change 2 (2):296-308. http://dx.doi.org/10.1002/wcc.97

Kalikoski, D. C., P. Q. Neto, and T. Almudi. 2010. Building adaptive capacity to climate variability: the case of artisanal fisheries in the estuary of the Patos Lagoon, Brazil. Marine Policy 34(4):742-751. http://dx.doi.org/10.1016/j.marpol.2010.02.003

Keskitalo, E. C. H., H. Dannevig, G. K. Hovelsrud, J. J. West, and Å. G. Swartling. 2011. Adaptive capacity determinants in developed states: examples from the Nordic countries and Russia. Regional Environmental Change 11(3):579-592. http://dx.doi. org/10.1007/s10113-010-0182-9

Kuhlicke, C., A. Steinführer, C. Begg, C. Bianchizza, M. Bründl, M. Buchecker, B. De Marchi, M. Di Masso Tarditti, C. Höppner, B. Komac, L. Lemkow, J. Luther, S. McCarthy, L. Pellizzoni, O. Renn, A. Scolobig, M. Supramaniam, S. Tapsell, G. Wachinger, G. Walker, R. Whittle, M. Zorn, and H. Faulkner. 2011. Perspectives on social capacity building for natural hazards: outlining an emerging field of research and practice in Europe. Environmental Science and Policy 14(7):804-814. http://dx.doi. org/10.1016/j.envsci.2011.05.001

Levin, K., B. Cashore, S. Bernstein, and G. Auld. 2012. Overcoming the tragedy of super wicked problems: constraining our future selves to ameliorate global climate change. Policy Sciences 45(2):123-152. http://dx.doi.org/10.1007/s11077-012-9151-0

Linnekamp, F., A. Koedam, and I. S. A. Baud. 2011. Household vulnerability to climate change: examining perceptions of households of flood risks in Georgetown and Paramaribo. Habitat International 35(3):447-456. http://dx.doi.org/10.1016/j. habitatint.2010.12.003

Maller, C. J., and Y. Strengers. 2011. Housing, heat stress and health in a changing climate: promoting the adaptive capacity of vulnerable households, a suggested way forward. Health Promotion International 26(4):492-498. http://dx.doi.org/10.1093/ heapro/dar003

Marshall, N. A., S. E. Park, W. N. Adger, K. Brown, and S. M. Howden. 2012. Transformational capacity and the influence of place and identity. Environmental Research Letters 7(3):1-9. http:// dx.doi.org/10.1088/1748-9326/7/3/034022

Marshall, N. A., S. Park, S. M. Howden, A. B. Dowd, and E. S. Jakku. 2013. Climate change awareness is associated with enhanced adaptive capacity. Agricultural Systems 117:30-34. http://dx.doi.org/10.1016/j.agsy.2013.01.003

McLaughlin, P., and T. Dietz. 2008. Structure, agency and environment: toward an integrated perspective on vulnerability. Global Environmental Change 18(1):99-111. http://dx.doi. org/10.1016/j.gloenvcha.2007.05.003

Measham, T. G., B. L. Preston, T. F. Smith, C. Brooke, R. Gorddard, G. Withycombe, and C. Morrison. 2011. Adapting to climate change through local municipal planning: barriers and challenges. Mitigation and Adaptation Strategies for Global Change 16(8):889-909. http://dx.doi.org/10.1007/s11027-011-9301-2 
Midgley, G., and M. Reynolds. 2004. Systems/operational research and sustainable development: towards a new agenda. Sustainable Development 12(1):56-64. http://dx.doi.org/10.1002/ $\underline{\text { sd. } 218}$

Miller, F., H. Osbahr, E. Boyd, F. Thomalla, S. Bharwani, G. Ziervogel, B. Walker, J. Birkmann, S. van der Leeuw, J. Rockstrom, J. Hinkel, T. Downing, C. Folke, and D. Nelson. 2010. Resilience and vulnerability: complementary or conflicting concepts? Ecology and Society 15(3): 11. [online] URL: http://www. ecologyandsociety.org/vol15/iss3/art11/.

Molua, E. L. 2009. Accommodation of climate change in coastal areas of Cameroon: selection of household-level protection options. Mitigation and Adaptation Strategies for Global Change 14(8):721-735. http://dx.doi.org/10.1007/s11027-009-9194-5

Moser, C. O. N. 1998. The asset vulnerability framework: reassessing urban poverty reduction strategies. World Development 26(1):1-19. http://dx.doi.org/10.1016/S0305-750X (97)10015-8

Moser, S. C., and J. A. Ekstrom. 2011. Taking ownership of climate change: participatory adaptation planning in two local case studies from California. Journal of Environmental Studies and Sciences 1(1):63-74. http://dx.doi.org/10.1007/s13412-011-0012-5

Nelson, D. R., W. N. Adger, and K. Brown. 2007. Adaptation to environmental change: contributions of a resilience framework. Annual Review of Environmental Resources 32:395-419. http://dx. doi.org/10.1146/annurev.energy.32.051807.090348

Nelson, R., P. Kokic, S. Crimp, H. Meinke, and S. M. Howden. 2010. The vulnerability of Australian rural communities to climate variability and change: part I-conceptualising and measuring vulnerability. Environmental Science and Policy 13 (1):8-17. http://dx.doi.org/10.1016/j.envsci.2009.09.006

Norris, F. H., S. P. Stevens, B. Pfefferbaum, K. F. Wyche, and R. L. Pfefferbaum. 2008. Community resilience as a metaphor, theory, set of capacities, and strategy for disaster readiness. American Journal of Community Psychology 41(1-2):127-150. http://dx.doi.org/10.1007/s10464-007-9156-6

OECD [Organisation for Economic Co-operation and Development]. 2008. Household behaviour and the environment: reviewing the evidence. OECD, Paris, France. [online] URL: http:// www.oecd.org/environment/consumption-innovation/42183878.pdf.

Olwig, M. F. 2012. Multi-sited resilience: the mutual construction of "local" and "global" understandings and practices of adaptation and innovation. Applied Geography 33:112-118. http:// dx.doi.org/10.1016/j.apgeog.2011.10.007

Osbahr, H., C. Twyman, W. N. Adger, and D. S. G. Thomas. 2008. Effective livelihood adaptation to climate change disturbance: scale dimensions of practice in Mozambique. Geoforum 39 (6):1951-1964. http://dx.doi.org/10.1016/j.geoforum.2008.07.010

Park, S. E., N. A. Marshall, E. Jakku, A. M. Dowd, S. M. Howden, E. Mendham, and A. Fleming. 2012. Informing adaptation responses to climate change through theories of transformation. Global Environmental Change 22(1):115-126. http://dx.doi. org/10.1016/j.gloenvcha.2011.10.003
Patterson, J. M. 2002. Understanding family resilience. Journal of Clinical Psychology 58(3):233-246. http://dx.doi.org/10.1002/ jclp. 10019

Peters, G. P., R. M. Andrew, T. Boden, J. G. Canadell, P. Ciais, C. Le Quéré, G. Marland, M. R. Raupach, and C. Wilson. 2013. The challenge to keep global warming below $2{ }^{\circ} \mathrm{C}$. Nature Climate Change 3:4-6. http://dx.doi.org/10.1038/nclimate1783

Renn, O. 2005. Risk governance: towards an intergrative approach. International Risk Governance Council, Geneva, Switzerland. [online] URL: http://www.irgc.org/IMG/pdf/IRGC WP No 1Risk_Governance reprinted_version_pdf.

Renn, O. 2008. Risk governance: coping with uncertainty in a complex world. Earthscan, London, UK.

Renn, O., and A. Klinke. 2012. Complexity, uncertainty and ambiguity in inclusive risk governance. Pages 59-76 in $\mathrm{T}$. Measham, and S. Lockie, editors. Risk and social theory in environmental management. CSIRO Publishing, Collingwood, Australia. [online] URL: http://www.publish.csiro.au/pid/6581. $\underline{\text { htm. }}$.

Renn, O., A. Klinke, and M. van Asselt. 2011. Coping with complexity, uncertainty and ambiguity in risk governance: a synthesis. Ambio 40(2):231-246. http://dx.doi.org/10.1007/ $\underline{\mathrm{s} 13280-010-0134-0}$

Renn, O., and P.-J. Schweizer. 2009. Inclusive risk governance: concepts and application to environmental policy making. Environmental Policy and Governance 19(3):174-185. http://dx. doi.org/10.1002/eet.507

Rickards, L., and S. M. Howden. 2012. Transformational adaptation: agriculture and climate change. Crop and Pasture Science 63(3):240-250. http://dx.doi.org/10.1071/CP11172

Saroar, M. M., and J. K. Routray. 2012. Impacts of climatic disasters in coastal Bangladesh: Why does private adaptive capacity differ? Regional Environmental Change 12(1):169-190. http://dx.doi.org/10.1007/s10113-011-0247-4

Scoones, I. 1998. Sustainable rural livelihoods: a framework for analysis. IDS Working Paper 72. Institute of Development Studies, Brighton, UK. [online] URL: http://www.ids.ac.uk/files/ dmfile/Wp72.pdf.

Sen, A. 1981. Poverty and famines: an essay on entitlement and deprivation. Clarendon Press, Oxford, UK.

Siegel, P. B. 2005. Using an asset-based approach to identify drivers of sustainable rural growth and poverty reduction in Central America: a conceptual framework. World Bank, Washington, D. C., USA. http://dx.doi.org/10.1596/1813-9450-3475

Smit, B., I. Burton, R. J. T. Klein, and J. Wandel. 2000. An anatomy of adaptation to climate change and variability. Climatic Change 45(1):223-251. http://dx.doi.org/10.1023/A:1005661622966

Smit, B., and J. Wandel. 2006. Adaptation, adaptive capacity and vulnerability. Global Environmental Change 16(3):282-292. http:// dx.doi.org/10.1016/j.gloenvcha.2006.03.008

Spence, A., and N. Pidgeon. 2009. Psychology, climate change and sustainable behaviour. Environment: Science and Policy for 
Sustainable Development 51(6):8-18. http://dx.doi. org/10.1080/00139150903337217

Strengers, Y., and C. Maller. 2012. Materialising energy and water resources in everyday practices: insights for securing supply systems. Global Environmental Change 22(3):754-763. http://dx. doi.org/10.1016/j.gloenvcha.2012.04.004

Thomsen, D. C., T. F. Smith, and N. Keys. 2012. Adaptation or manipulation? Unpacking climate change response strategies. Ecology and Society 17(3): 20. http://dx.doi.org/10.5751/ ES-04953-170320

Tompkins, E. L., W. N. Adger, E. Boyd, S. Nicholson-Cole, K. Weatherhead, and N. Arnell. 2010. Observed adaptation to climate change: UK evidence of transition to a well-adapting society. Global Environmental Change 20(4):627-635. http://dx. doi.org/10.1016/j.gloenvcha.2010.05.001

Tschakert, P., B. van Oort, A. L. St. Clair, and A. LaMadrid. 2013. Inequality and transformation analyses: a complementary lens for addressing vulnerability to climate change. Climate and Development 5(4):340-350. http://dx.doi.org/10.1080/17565529.2013.828583

Tucker, C. M., H. Eakin, and E. J. Castellanos. 2010. Perceptions of risk and adaptation: coffee producers, market shocks, and extreme weather in Central America and Mexico. Global Environmental Change 20(1):23-32. http://dx.doi.org/10.1016/j. gloenvcha.2009.07.006

Ulrich, W. 2000. Reflective practice in the civil society: the contribution of critically systemic thinking. Reflective Practice 1 (2):247-268. http://dx.doi.org/10.1080/713693151

Ulrich, W. 2005. A mini-primer of critical systems heuristics. Revised version of Ulrich, W. 2002. Critical systems heuristics. Page 72-73 in H. G. Daellenbach and R. L. Flood, editors. The informed student guide to management science. Thomson Learning, London, UK. [online] URL: http://wulrich.com/csh. $\underline{\text { html. }}$.

van Asselt, M. B. A., and O. Renn. 2011. Risk governance. Journal of Risk Research 14(4):431-449. http://dx.doi.org/10.1080/13669$\underline{877.2011 .553730}$

Vincent, K. 2007. Uncertainty in adaptive capacity and the importance of scale. Global Environmental Change 17(1):12-24. http://dx.doi.org/10.1016/j.gloenvcha.2006.11.009

Waitt, G., P. Caputi, C. Gibson, C. Farbotko, L. Head, N. Gill, and E. Stanes. 2012. Sustainable household capability: Which households are doing the work of environmental sustainability? Australian Geographer 43(1):51-74. http://dx.doi. org/10.1080/00049182.2012.649519

WSAA [Water Services Association of Australia]. 2010. Implications of population growth in Australia on urban water resources. Occasional Paper 25. WSSA, Melbourne, Australia. [online] URL: https://www.wsaa.asn.au/WSAAPublications/ Documents/Occasional $\% 20$ Paper $\% 2025 \% 20$

Implications $\% 20$ of $\% 20$ population $\% 20$ growth $\% 20$ in $\% 20$ Australia $\%$ 20on $\% 20$ urban $\% 20$ water $\% 20$ resources $\% 20$ July $\% 202010$.pdf.
Ziervogel, G., S. Bharwani, and T. E. Downing. 2006. Adapting to climate variability: pumpkins, people and policy. Natural Resources Forum 30(4):294-305. http://dx.doi.org/10.1111/ j.1477-8947.2006.00121.x 